\title{
Development and Performance Evaluation of a Dual Heat Dryer; a Renewable Energy Technology for Sustainable Processing of Agro-Produce
}

\author{
M.A.S. Upul Kumara, H.S. Jayewardene, K.G.L.R. Jayathunga, D.P. Senanayake \\ and K.B. Palipane
}

Abstract: Rural agricultural sector in developing countries such as Sri Lanka is still lacking efficient and cost effective devices for processing of agricultural produce. A dual heat dryer which utilises rice husk and solar energy for thermal energy generation required for the drying process was designed and developed at the Institute of Post Harvest Technology (IPHT), Sri Lanka for dehydration of agricultural produce. Performance evaluation of the dual heat dryer gave promising results for adoption by the farming community. The dryer is able to generate drying air temperatures ranging from 40 to $110^{\circ} \mathrm{C}$ thus, facilitating a variety of crop produce to be dried, such as drumsticks, bitter gourd, papaya, mango, lemon grass, mushroom and many more, with natural convection airflow. In most instances drying using solar energy alone is insufficient to accomplish the drying operation because the drying process has to be continued up to 10-15 hrs extending into the night. The incorporation of biomass energy into solar drying enables the drying process to be continued even in the absence of sun shine and thereby ensuring product quality. The benefit/cost ratio is 10:1 in the dryer and hence adoption by the farming community or in rural areas is extremely feasible. Furthermore, the renewable energy technology discussed in this paper would help to enhance the socio-economic development of the rural community in developing countries like Sri Lanka.

Key Words : $\quad$ Paddy Husk, Solar Energy, Furnace, Drying, Agro Processing

\section{Introduction}

Fulfilling energy requirements for drying of agro produce as a method of preservation, demands a substantial proportion of the cost of production. In Sri Lanka too, devices for drying of agricultural produce using low operational costs will be attractive to the farmers in ensuring value added products to be offered to the market at a competitive price.

The capacity of currently available dryers which utilize solar energy is often inadequate to be utilised for viable micro enterprises. Hence, the capacity of any such dryer should be at least 1000 $\mathrm{kg}$ per batch. The small scale entrepreneurs have made requests to have a dryer of this capacity for their fruit and vegetable dehydration. Even though biomass fuelled dryers are widely used, especially in tobacco drying, attention has not been paid to harness freely available solar energy without direct exposure of the drying materials to UV rays present in the solar spectrum. Hence there is an urgent necessity to design efficient and cost effective dryer that utilise renewable energy sources in order to benefit rural farming community. Any dryer requires temperature controlling device due to microbial growth in low temperatures and food deterioration in high temperatures. Therefore, both energy from rice husk combustion and solar energy are utilised in this dryer to fulfil the energy required for drying process

High moisture content of any agro produce leads to deterioration due to physiological and microbiological activities resulting in a serious post harvest losses amounting to $30-40 \%$ [12]. Drying of agro produce requires thorough attention on temperature of drying air.

A dual heat dryer was designed at the Institute of Post Harvest Technology (IPHT),

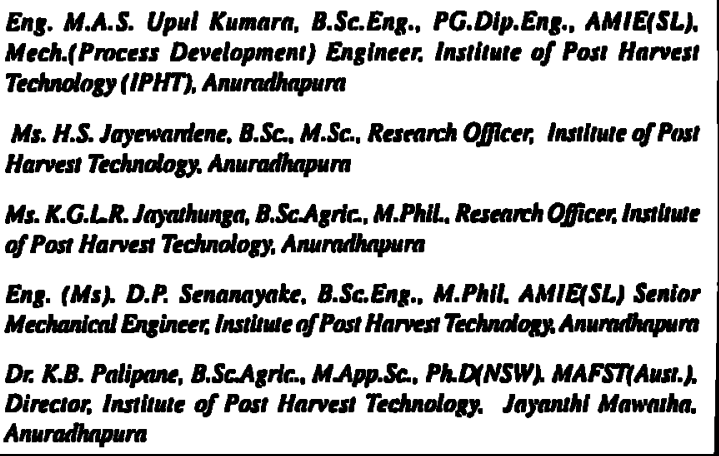

Eng. M.A.S. Upul Kumarn, B.Sc.Eng., PG.Dip.Eng., AMIE(SL), Mech.(Process Development) Engineer, Instilute of Post Harvest Technology (IPHT), Anumathourm Harvest Technology. Anuradhapur

Ms. K.G.LR. Jayouhunga, 8.Sc-Agrif, M.Phll. Research Oficer, Inniuur of Past Harvest Technology: Anumdhqum Anuradhoura 
Anuradhapura, Sri Lanka to achieve the objectives shown above. The heat emanated from the combustion of biomass in synergy with the energy in solar radiation helped the drying process in a very sustainable manner and this could lead to new horizons for the end users of conventional energy sources.

Since more environmental legislation and management practices are gradually becoming critical in almost all the activities in the society, more sustainable solution in agro produce drying is examined through these activities paying special attention to the energy usage from biomass combustion coupled with solar energy.

\section{Dryer Design}

\subsection{Design of Solar Air Heater}

The solar air heater designed at IPHT is very simple in construction and operation. It consists of a glass covering, a heat absorbing material and an air flow control device. The transmittance of solar energy is comparably high in plane glasses and the cost is also considerably low. The plastics sheets were also tested, but it gave unpromising results as a covering material during exposing to a longer period of 12 months. Therefore, plane glass was selected as the covering material for the solar air heater. Gneiss was selected as the best heat absorbing material based on a laboratory test. The materials selected were easy to be purchased or supplied by a farmer. Considering the equation for the 'Pick-up efficiency' given below, the collector area was determined.

$$
\eta_{c}=\frac{1}{\left(1+U_{L} / h\right)} \cdot\left[1-e^{\left(-U / \sigma_{1} G_{0}\right)}\right] \cdot \frac{G_{2} \cdot C_{p} \cdot f_{a}}{U_{0}}
$$

Where,

$U_{\mathrm{L}}=$ Collector heat loss coefficient, $\left(\mathrm{Wm}^{-2} \mathrm{~K}^{-1}\right)$,

$h=$ heat transfer coefficient $\left(\mathrm{Wm}^{-2} \mathrm{~K}^{-1}\right)$,

$U_{0}=$ Overall heat transfer coefficient, $\left(\mathrm{Wm}^{-2} \mathrm{~K}^{1}\right)$,

$\mathrm{G}_{\mathrm{a}}=$ Mass flow rate per unit collector area, $\left(\mathrm{kgs}^{-1} \mathrm{~m}^{-2}\right)$,

$C_{p}=$ Specific heat of air, $\left(\mathrm{kJ}_{\mathrm{p}} \mathrm{kg}^{-1} \mathrm{~K}^{-1}\right)$,

$f_{c a}=$ effective transitivity absorptivity product,

$\mathrm{k}=$ air thermal conductivity $\left(\mathrm{W} \mathrm{m}^{-1} \mathrm{~K}^{-1}\right)$, For single cover glass $=0.6$, $f_{c a}=0.83, U_{L}=6.99$,

$\mathrm{U}_{\mathrm{o}}=5.3$

$U / G_{a} . G_{p}=0.131$

Following assumptions were made in determining above values.

1). Air flow rate $=40.8 \times 10^{-3} \mathrm{kgs}^{-1} \mathrm{~m}^{-2}$

2). Heat transfer coefficient $=22.7 \mathrm{Wm}^{-2} \mathrm{~K}^{-1}$

3). Rear \& edge heat losses are $10 \%$ of upward heat loss.

4). Glass thickness is $2.5 \mathrm{~mm}$ \& tedler thickness is $0.1 \mathrm{~mm}$.

5). Absorptivity of absorber $=0.95$

6). $f_{c}$ is taken as 0.85 of the effective transmissivity absorptivity product at normal incidence.

7). Sky temperature taken as approximately $5^{\circ} \mathrm{C}$ below ambient, wind speed $5 \mathrm{mph}\left(2.5 \mathrm{mS}^{-1}\right)$. Substituting above values to equation [1] above,

$$
\eta_{c}=0.596
$$

From following equation, the "Overall drying. efficiency', is determined

$\eta_{c}=\left(v \cdot \rho \cdot C_{p} \cdot \Delta T / A_{c} . I_{c}\right) \cdot 100 \%$

Where,

$\mathrm{V}=$ Volumetric flow rate of air $\left(\mathrm{m}^{-3} \cdot \mathrm{S}^{-1}\right)$

$\rho=$ Air density (kg.m ${ }^{-3}$ )

$\Delta \mathrm{T}=$ Air temperature elevation $\left({ }^{\circ} \mathrm{C}\right)$

$C_{p}=$ Air specific heat $\left(0 \cdot \mathrm{kg}^{-1} \cdot \mathrm{K}^{-1}\right)$

$A_{c}=$ Collector area $\left(m^{2}\right)$

$I_{c}=$ Isolation on collector area (W. $\left.\mathrm{m}^{-2}\right)$

According to above equation,

$A_{c}=\left(v . \rho . C_{p} . \Delta T / \eta_{c} . I_{c}\right)$.

$\rho=1.28 \mathrm{~kg} \cdot \mathrm{m}^{-3}$

$\Delta \mathrm{T}=55^{\circ} \mathrm{C}-30^{\circ} \mathrm{C}=25^{\circ} \mathrm{C}$

$\mathrm{C}_{\mathrm{p}}=1.030 \mathrm{~J} \cdot \mathrm{kg}^{-1} \cdot \mathrm{K}^{-1}$

$\eta_{c}=0.596$

$A_{c}=13.368 \mathrm{~m}^{2}$ 


\subsection{Design of biomass fired furnace}

The furnace volume is treated as top priority in designing the paddy husk fired furnaces.

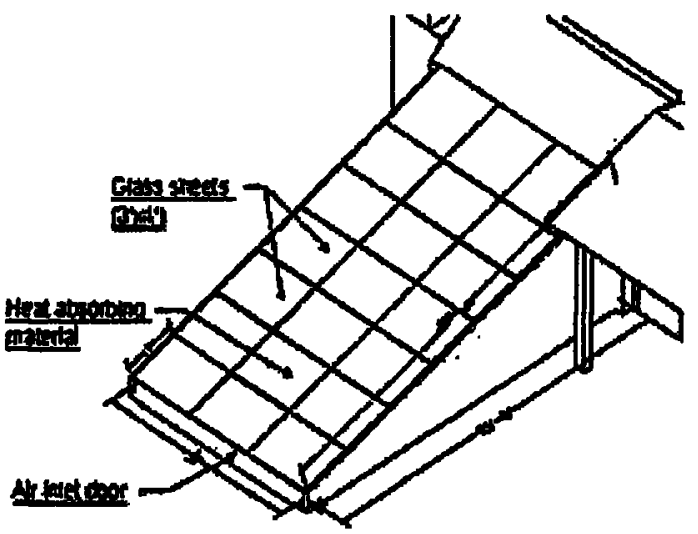

Figure 1: Solar air heater used for capturing solar energy

After determining the volume, the geometric configuration of furnace could be designed by taking the construction aspects also into account. Two principle design equations used in the design process are given below [3].

$Q_{A}=\frac{W \cdot C_{n}}{A} \quad \mathrm{kJm}^{-2} \cdot \mathrm{hr}^{-1}$

$Q_{v}=\frac{W \cdot C_{n}}{v} \mathbf{k J m}^{-2} \cdot \mathbf{h r}^{-1}$

Where,

$Q_{A}=$ thermal load of furnace grate area $\left(\mathrm{kJm}^{-2} \cdot \mathrm{hr}^{-1}\right.$ $V=$ volume of furnace space in $\left(\mathrm{m}^{3}\right)$

$Q_{v}=$ thermal load of furnace volume $\left(\mathrm{kJm}^{-3} \cdot \mathrm{hr}^{-1}\right)$

$A=$ furnace grate area $\left(\mathrm{m}^{2}\right)$

$C_{n}=$ net calorific value of the fuel (kJ.kg $\left.{ }^{-1}\right)$

$\mathrm{W}=$ fuel combusted $\left(\mathrm{kg}_{\mathrm{g}} \mathrm{hr} \mathbf{r}^{-1}\right)$

In designing the furnace, the thermal loads of furnace grate area and furnace volume of the paddy husk were estimated using the existing data. The necessity for above estimation is mainly due to the material properties.
Ordinary masonry bricks were selected in place of the cast iron fire bars and the refractory bricks. The specific heats of steel, brickwork, Rubber and wood are 0.12 , about $0.2,0.415$ and

$0.45-0.65 \mathrm{Cal} / \mathrm{g}{ }^{\circ} \mathrm{C}$ respectively [6]. Since the specific heat capacity of masonry bricks is higher than that of cast iron, the heat load on the grate area would be smaller in grates constructed using masonry bricks.

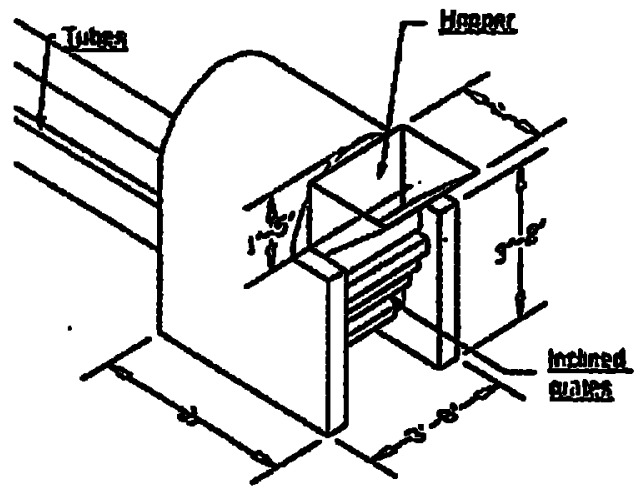

Figure 2 : Furnace used for biomass combustion

The estimations based on the above factors have put into practice after several modifications yielded thermal load on grate area as well as that on furnace volume was estimated to $8.5 \times 10^{3}$ $\mathrm{kJ} / \mathrm{m}^{2} . \mathrm{hr}$ and $6.5 \times 105 \mathrm{~kJ} / \mathrm{m}^{3} . \mathrm{hr}$ respectively. The estimated values lie between the standard values according to Table 1 . Chemical composition of the fuel used is given in Table 01 .

\subsection{Selection of the air flow}

Designing the air flow is based on the moisture transfer to the air from the agro produce being dried. The most crops require an air flow ranging $0.2-0.8 \mathrm{~m} / \mathrm{s}$. Therefore, taking the normal wind speed in to consideration, 14".(355.6 mm) turbo ventilators were chosen to create the required air flow through the drying chamber.

Table 1:

Design parameters used

\begin{tabular}{|l|c|c|c|}
\hline \multirow{2}{*}{ Parameter } & \multicolumn{3}{|c|}{ Fuel used } \\
\cline { 2 - 4 } & $\begin{array}{c}\text { Value for powdered } \\
\text { husk [3] }\end{array}$ & Fire wood [3] & $\begin{array}{c}\text { Value used in } \\
\text { design }\end{array}$ \\
\hline $\begin{array}{l}\text { Thermal load on furnace grate area } \\
/\left(\mathrm{kJ} / \mathrm{m}^{2} . \mathrm{hr}\right) \\
\text { Thermal load on furnace volume } \\
/\left(\mathrm{kJ} / \mathrm{m}^{3} . \mathrm{hr}\right)\end{array}$ & $(8.36-8.78) \times 10^{5}$ & $(2.51-3.34) \times 10^{6}$ & $8.5^{4} \times 10^{5}$ \\
\hline
\end{tabular}


Table 2 :

Chemical composition used; $100 \mathrm{~kg}$ basis [3]

\begin{tabular}{|c|c|c|c|}
\hline Rice husk constituents & $\begin{array}{c}\text { Weight constituent } \\
/(\mathbf{k g})\end{array}$ & $\begin{array}{c}\text { Matter constituent/ } \\
(\mathbf{k m o l})\end{array}$ & $\begin{array}{c}\text { Required } \mathrm{O}_{2} \\
/ \text { (kmol) }\end{array}$ \\
\hline $\mathrm{C}$ & 39.0 & 3.25 & 3.25 \\
$\mathrm{H}_{2}$ & 5.0 & 2.5 & 1.25 \\
$\mathrm{O}_{2}$ & 32.7 & 1.022 & 1.022 \\
$\mathrm{~S}$ & 0.1 & 0.003 & 0.003 \\
$\mathrm{~N}_{2}$ & 2.0 & 0.071 & - \\
$\mathrm{H}_{2} \mathrm{O}$ & 3.6 & 0.2 & - \\
& Total & 3.481 \\
\hline
\end{tabular}

The constant rate period lies between 6 to $8 \mathrm{hrs}$ where as the falling rate would be the rest of the time. The total time depends on the crop produce and the way it is prepared. The laboratory tests gave approximate times for the design activity.

\section{Materials and Method}

\subsection{Construction Methodology}

The normal foundation was laid using bricks. Special attention was paid on the preparation of cement paste in the construction process of furnace. Since the hydration of cement paste produces $\mathrm{Ca}(\mathrm{OH})_{2}$ in the pores of the bulk paste, cracks are formed in the presence of heat due to inconsistency caused by dissolving the reactive compounds in fine aggregate in $\mathrm{Ca}(\mathrm{OH})_{2}$ [12]. To achieve consistency in the cement paste, the following mixture proportions were used. Sand (two portions), cow dung (one portion), clay (one and half) portions), Paddy husk ash (one portion), cement (half portions) in volume basis could be taken. The best way of preparation of the paste should be as described in the following steps.

1. Mixing of 2 parts of sand and 0.5 parts of cement (OPC) thoroughly under dry conditions

2. Addition of 1 part of paddy husk ash and mixing well again

3. 1.5 parts of finely crushed clay is then added and mixed

4. 3 parts of water and 1 part of cow dung are thoroughly mixed and then filtered.

5. The filtrate and the mixture obtained in step 3 should be mixed to make the binding paste.
Solar air heater was manufactured using metal as the best heat absorbing material [11] and ordinary glass was selected as the transparent cover.

The trays were fabricated using stainless steel wire mesh and mounted on a structure made up of slotted angles.

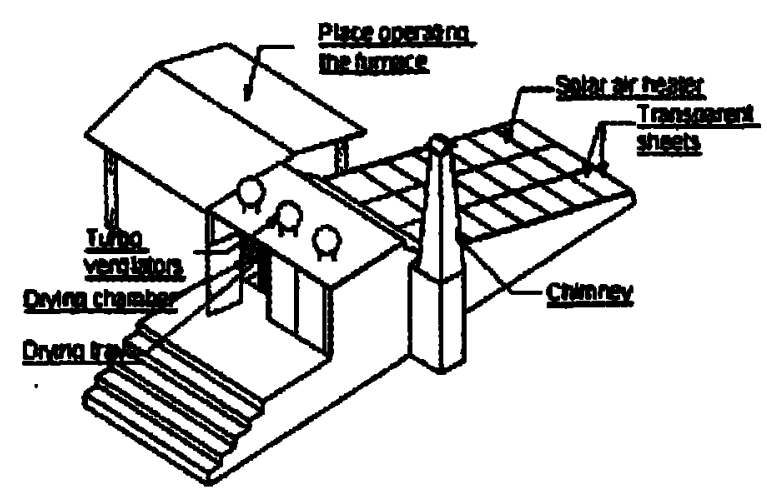

Figure 3 : Isometric view of the solar assisted paddy husk fuelled dryer

\subsection{Operation Methodology}

\section{Operating Grate Furnace}

Operating furnaces require substantial attention so that to ensure the combustion and the flue gas generated to pass through the tubes of the heat exchanger. Furnace in dryers requires only about $2 \mathrm{~L}$ of kerosene whereas furnace for smoke generation requires about $2 \mathrm{~L}$ of kerosene and about $15 \mathrm{~kg}$ of firewood in starting up the operation. Following procedures have to be followed when operating either type of furnaces for any application. 
- Substantial amount of paddy husk is mixed with $1 \mathrm{~L}$ of kerosene in the feed hopper.

- Using the husk feeding regulator, a portion of the kerosene treated paddy husk is fed to the furnace in the free falling manner through the grates.

- The retained paddy husk on the grates is ignited.

- Once the flame is sustained, the husk feeding regulator can be operated to ensure the continuous combustion in the furnace.

- After initial ignition took place, treating paddy husk with kerosene is not necessary.

- If the flame is off due to over loading of the grates, a small quantity of kerosene should be sprayed through grates and reignite the furnace.

- Once the heap of ash is collected up to about $0.3 \mathrm{~m}$ of the furnace, removing a portion of ash collected would be necessary.

- Requirement of paddy husk depend on the designer's recommendations

\subsection{Testing Procedures}

The experiment was conducted in the solar assisted paddy husk dryer while keeping the sun drying as the control treatment. The effectiveness of the dryer was tested by comparing with the electrical dryer manufactured by the National Engineering Research and Development (NERD) centre of Sri Lanka.

\subsection{Processing procedures}

Drumsticks: Undamaged and disease free drumsticks of uniform maturity stage were selected, peeled and cut into strips of $7.5 \mathrm{~cm}$ pieces. The drumsticks strips were subjected to hot water $\left(60^{\circ} \mathrm{C}\right)$ blanching treatment for $3 \mathrm{~min}$ with $0.05 \% \mathrm{NaHCO}_{3}$. The samples were drained and dried using sun drying, and at $55 \mathrm{OC}$ in the solar assisted dryer and electrical dryer.

Bitter gourd: Undamaged and disease free bitter gourd of uniform maturity stage were selected, washed and sliced into $3 \mathrm{~mm}$ thickness. The slices were immersed in hot water at $60^{\circ} \mathrm{C}$ for blanching treatment for $3 \mathrm{~min}$ with $0.5 \%$ salt and $0.1 \%$ $\mathrm{NaHCO}_{3}$. The samples were drained and dried using sun drying, and at $55 \mathrm{oC}$ in the solar assisted dryer and electrical dryer.
Papaya: Undamaged and disease free ripe papaya of variety 'Red lady" was selected, washed and sliced into $5 \mathrm{~mm}$ thickness. The sliced papayas were directly dried using sun drying and at 55 $O C$ in the solar assisted dryer and electrical dryer.

Mango: Undamaged and disease free ripe mango of indigenous variety 'Petti amba" was selected, washed and sliced into $5 \mathrm{~mm}$ thickness. The sliced mangoes were directly dried using sun drying and at $55^{\circ} \mathrm{C}$ in the solar assisted dryer and electrical dryer.

\subsection{Analysing procedures}

\section{Drying and drying rate curoe}

The drying curve was constructed by plotting the residual moisture content against corresponding drying time. The residual moisture content was determined at each intervals using moisture analyser (Ohaus, Model: MB-45) and drying times for each commodity were selected. The drying rate curve was constructed by plotting the drying rate as a function of drying time.

\section{Physical parameter analyses}

The rehydration ratio of the dehydrated product was determined in triplicate by taking the sample weight before and after rehydration in boiling water for $8 \mathrm{~min}$ according to the method of Ranganna [7]. Water activity of the dehydrated products was determined in triplicate using a water activity meter (Pawkit). Data on the physico-chemical parameter analysis were subjected to analysis of variance (ANOVA). General Linear Model Procedure developed by Statistical Analysis System (SAS Institute. Inc, 1994) was used to perform ANOVA. Treatment means were compared at $p<0.05$ according to the Duncan New Multiple Range Test (DNMRT).

\section{Seusory evaluation}

The acceptability of the products dried by the dryer was tested by using a sensory panel with thirty panelists. Drumsticks and bitter gourd were served after rehydrating in a boiling water for 30 $\mathrm{min}$, followed by cooking for $20 \mathrm{~min}$ and frying with coconut oil, respectively. Papaya and mango were served directly without further processing. Each prepared samples were rated on colour, odour, texture, taste and overall acceptability using five-point Hedonic scale (1-extremely dislike, 5-extremely like) and results were analysed by the Friedman test of the MINITAB statistical package. 


\section{Microbiological analysis}

Total plate counts (TPC) of microbes were analyzed using the method described in SLS: 516 - part 1 (1991).[10].

\section{Results and Discussion}

Effect of drying method on drying time of commodities is shown in Table 3 . According to the results of time taken for dehydration, the electrical and solar assisted paddy husk dryers are more effective compare to sun drying, may be due to the uniform exposure of the samples to the drying condition. Ambrose and Sreenarayanan [1] evaluated solar cabinet dryer to dehydrate garlic and compared with sun drying. They reported that both methods were weather dependant and took $10 \mathrm{hr}$ and $22 \mathrm{hr}$, respectively to dehydrate the commodity.

The residual moisture content as a function of drying time is shown in Figure 1. Bitter gourd, papaya and mango showed similar pattern of drying curves, while drumstick deviated.

At the same time the drying rate of drumsticks is more or less uniform throughout the drying may be due to the hard peel. During drying, an increasing rate, followed by decreasing rate of drying was observed in bitter gourd, papaya and mango. Bitter gourd showed the highest drying rate, while drumsticks showed the lowest drying rate may be due to different cell structures.

Table 3 :

Effect of drying method on drying time of commodities

\begin{tabular}{|l|c|c|c|}
\hline \multirow{2}{*}{ Commodity } & \multicolumn{3}{|c|}{ Drying method } \\
\cline { 2 - 4 } & $\begin{array}{c}\text { Solar assisted paddy } \\
\text { husk drying }\end{array}$ & Sun drying & Electrical drying \\
\hline Drumsticks & $38 \mathrm{hr}$ & 3 days & $15 \mathrm{hr}$ \\
Bitter gourd & $12 \mathrm{hr}$ & 2 days & $8 \mathrm{hr}$ \\
Papaya & $22 \mathrm{hr}$ & 2 days & $11 \mathrm{hr}$ \\
Mango & $8 \mathrm{hr}$ & 3 days & $8 \mathrm{hr}$ \\
\hline
\end{tabular}

Table 4 :

Effect of drying method on physico-chemical properties and microbiological quality of dehydrated products

\begin{tabular}{|c|l|c|l|l|}
\hline Commodity & \multicolumn{1}{|c|}{ Parameter } & $\begin{array}{c}\text { Solar assisted paddy } \\
\text { husk drying }\end{array}$ & Sun drying & Electrical drying \\
\hline Drumsticks & Moisture & $11.31^{\mathrm{a}}$ & $11.31^{\mathrm{a}}$ & $11.06^{\mathrm{b}}$ \\
& Water activity & $0.60^{\mathrm{a}}$ & $0.60^{\mathrm{a}}$ & $0.57^{\mathrm{b}}$ \\
& R ratio & $3.45^{\mathrm{ab}}$ & $3.21^{\mathrm{b}}$ & $3.67 \mathrm{a}$ \\
& Plate count & $8.4 \times 104^{\mathrm{b}}$ & $1.1 \times 10^{6 \mathrm{a}}$ & $6.4 \times 10^{\mathrm{b}}$ \\
& Moisture & $10.14^{\mathrm{a}}$ & $9.67^{\mathrm{a}}$ & $8.41^{\mathrm{b}}$ \\
& Water activity & $0.47^{\mathrm{a}}$ & $0.48^{\mathrm{a}}$ & $0.49^{\mathrm{a}}$ \\
& R ratio & $6.13^{\mathrm{a}}$ & $4.89^{\mathrm{b}}$ & $6.42^{\mathrm{a}}$ \\
& Plate count & $4.6 \times 104^{\mathrm{b}}$ & $4.6 \times 105^{\mathrm{a}}$ & $4.5 \times 103^{\mathrm{b}}$ \\
& Moisture & $13.47^{\mathrm{a}}$ & $13.99^{\mathrm{a}}$ & $11.37^{\mathrm{b}}$ \\
& Water activity & $0.44^{\mathrm{a}}$ & $0.43^{\mathrm{a}}$ & $0.40^{\mathrm{b}}$ \\
& R ratio & $4.67^{\mathrm{a}}$ & $4.46^{\mathrm{a}}$ & $4.59^{\mathrm{a}}$ \\
& Plate count & $1.7 \times 104^{\mathrm{b}}$ & $9.4 \times 104^{\mathrm{a}}$ & $1.4 \times 104^{\mathrm{c}}$ \\
& Moisture & $14.50^{\mathrm{b}}$ & $15.00^{\mathrm{b}}$ & $15.10^{\mathrm{a}}$ \\
& Water activity & $0.54^{\mathrm{ab}}$ & $0.56^{\mathrm{b}}$ & $0.53^{\mathrm{b}}$ \\
& R ratio & $2.68^{\mathrm{b}}$ & $2.64^{\mathrm{b}}$ & $2.87^{\mathrm{a}}$ \\
& Plate count & $1.1 \times 104^{\mathrm{b}}$ & $2.0 \times 104^{\mathrm{a}}$ & $4.5 \times 103^{\mathrm{c}}$ \\
\hline
\end{tabular}

Each value represents mean of three replicates. Means in the each raw followed by different letters are significantly different at $\mathrm{p}=0.05$. 
Initially, all commodities showed higher drying rate confirming the finding that in the initial stages, wet agricultural materials behave as like surfaces saturated with water [2]. The whole drying took place during increasing and falling rate periods and there was no constant drying rate period. These observations are line with those reported by Garg and Bhargava [4] for vegetables and fruits.
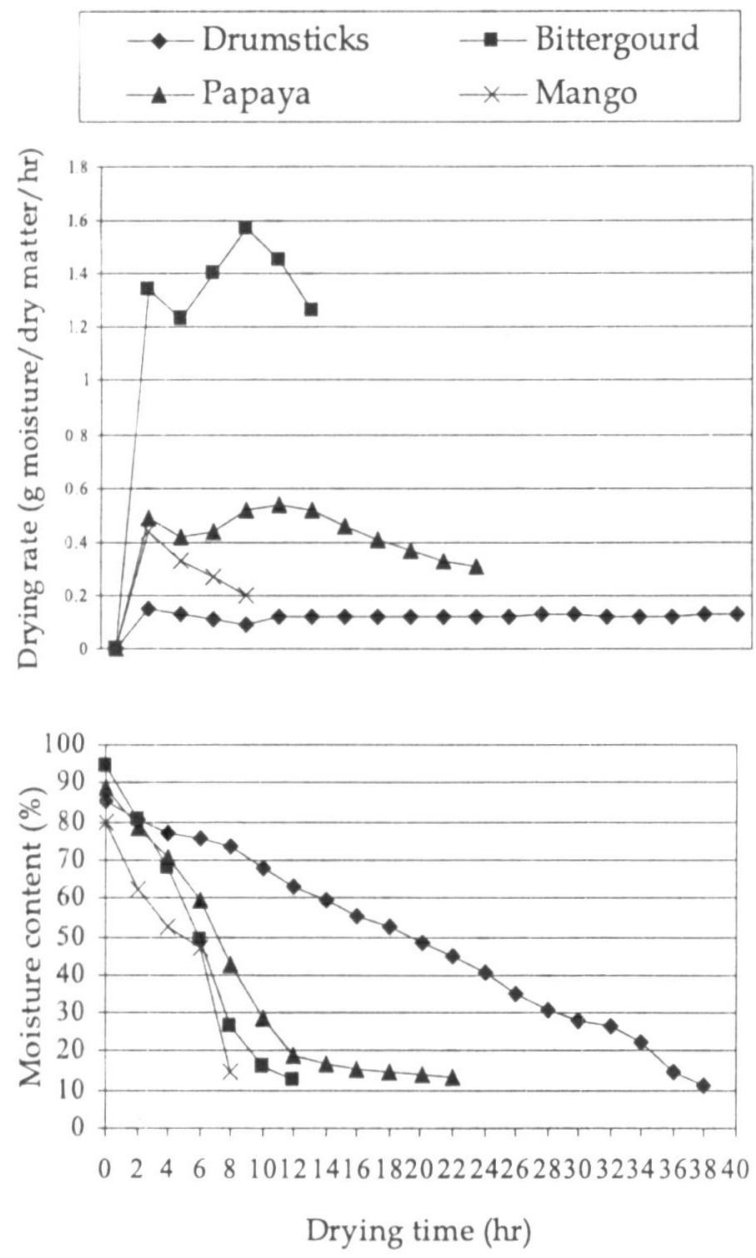

Figure 4 : Drying rate and drying curve for dehydration of drumsticks, bittergourd, papaya and mango in solar assisted paddy husk fired dryer .

Water activity of all dehydrated products reduced to below 0.6 after drying. Except bitter gourd, all products dehydrated in the electrical dryer showed the least water activity. The water activity of a food provides an objective measure of the amount of water available for micro organisms [4] Total colony forming units (CFU) of the dehydrated products, dried by the solar assisted paddy husk dryer were around $1 \times 10^{4}$ per gram. It was within the range of 104 recommended by Jay [5]. The growth and metabolism of micro organisms mainly depend on the presence of water available for microbial usage. Generally, bacteria require water activity $\left(a_{w}\right)$ of above 0.91 , yeast above 0.88 and mould above 0.75 . The developed products had aw of below 0.60 and this factor may be the reason for CFU/g of below 104

- Solar assisted paddy husk drying Sun drying

$\square$ Electrical drying
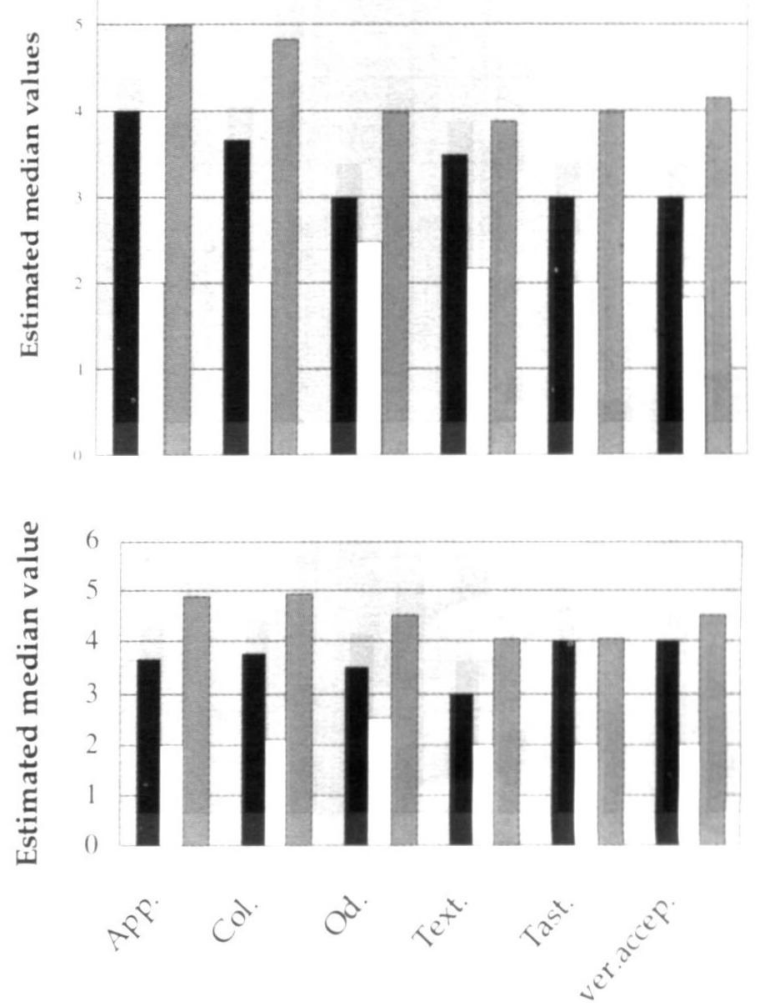

Figure 5 : Effect of drying method on sensory quality attributes of drumsticks and bittergourd

Except papaya, the rehydration ratio of electrically dried commodities showed the highest value however the values were not significantly difference with the samples dried using solar assisted paddy husk dryer. The higher rehydration ratio observed in this study may probably be due to minimum changes in the structure at the low drying temperature of $55^{\circ} \mathrm{C}$.

Effect of drying methods on organoleptic qualities of dehydrated products is described in Figures 2 and 3 . The results indicate that electrically dried samples were the best. However, there were no significant differences between solar assisted paddy husk dryer and the electrical dryer. Sun dried samples were not at the acceptable level. 
The samples dried by the conventional sun drying method were contaminated by insects, their excreta, mould and other extragenious foreign matter. At the same time the colour of the end products was turned to brownish and not uniform due to longer exposure to sun. These may be the reasons for rejecting the sun dried samples by the sensory panel.

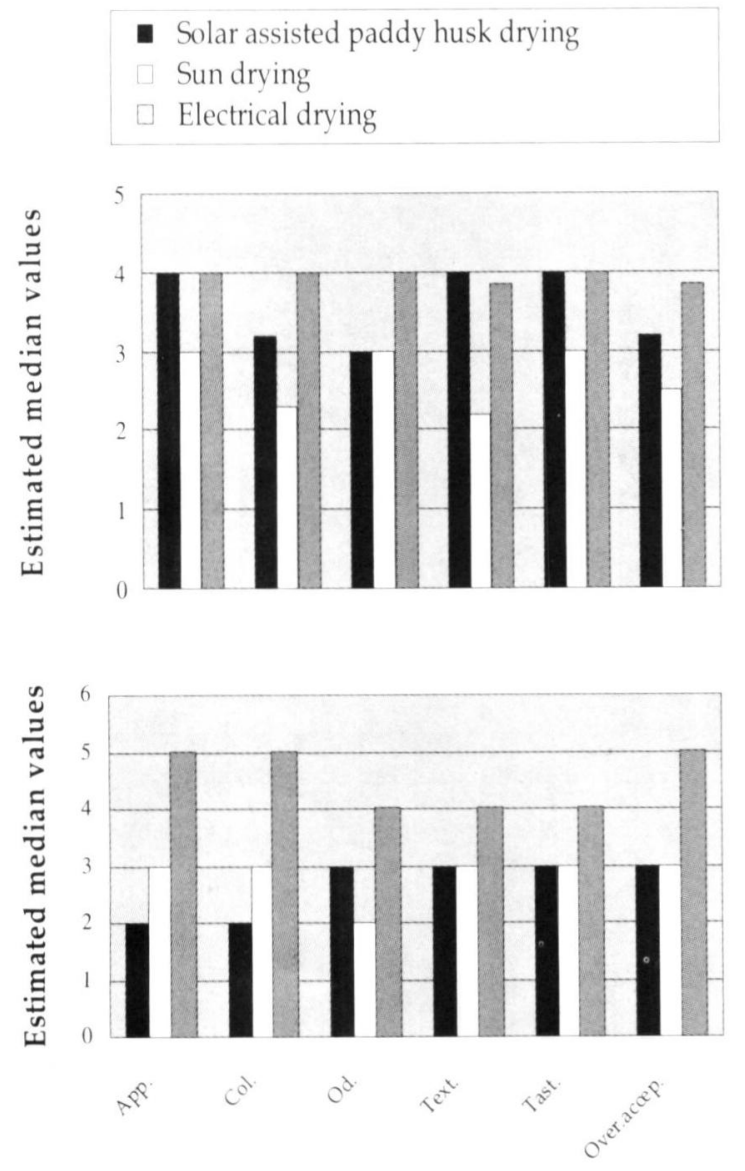

Figure 6 : Effect of drying method on sensory quality attributes of papaya and mango

Even though the open sun drying is supposed to be a low cost method, the results revealed that the end product has an inferior quality in terms of physico-chemical, microbiological and organoleptic qualities

Ratti and Mujumdar [8] have also reported that open sun drying, which is commonly practiced in tropical counties is a time consuming, weather dependant method with problems of contamination, infestation and microbial attack.

\section{Conclusions}

Since the amount of crop produce to be dried will determine the required heat load of air, the sizing of the furnace as well as the size of the solar collector has to be adjusted accordingly.

\section{Acknowledgement}

Sincere thanks are due to Sri Lanka Council of Agricultural Research and Policy (SLCARP) for financially supporting this research project. Authors also like to acknowledge the services other members of the Institute of Post Harvest Technology (IPHT) in Sri Lanka for their fullest corporation extended in this connection.

\section{References}

1. Ambrose, D.C.P. and Sreenarayanan, V.V. Studies on the dehydration of garlic. J. Food Science and Technology. Vol 35(3): pp 242-244, 1998

2. Brennan, J.G. Butters, J.R. and Cowell N.D. Lilley A.E. Food Engineering operations. Elsevier Applied Sciences. London, 1990.

3. Chakraverty, A. Biotechnology and other alternative technologies, Oxford and IBH publishing Co. (Pvt) Ltd. 1989, PP 21-52.

4. Garg, H.P. and Bhargava A.K. Solar drying models. Solar drying In: Proc. of National Workshop. Himanshu publications. Udaipur. pp18-49, 1989

5. Jay, J.M. Indicators of food microbial quality and safety. In. Modern Food Microbiology. Chapman and Hall, New York, pp.431-432. 1992

6. Perry, R.H. and Green D.W., Perry's Chemical Engineers' Handbook, McGraw Hill Inc., $7^{\text {th }}$ Edition, pp 2-186, 12-45, 1997,

7. Ranganna, S. Hand Book of Analysis and Quality Control of Fruit and Vegetable Producta. Tata McGraw Hill Publishing Co. Ltd., New Delhi, pp. 931-932. 1986.

8. Ratti, C. and Mumdar, A.S. Solar drying of foods; modelling and numerical stimulation. Solar Energy. Vol 60: pp151-157, 1997

9. SAS Institute Inc. SAS User's Guide: Statistics. SAS Institute Inc. Cary, NC, 1994

10. Sri Lanka Standards:516. Microbiological test methods, part 1-General guidance for enumeration of micro organisms colony count technique, 1991

11. Upul Kumara, M.A.S. and N.M.A. Wijesekara, Private study to identify the best heat absorbing material, conducted at IPHT, Anuradhapura Sri Lanka, 2004

12. Upul Kumara, M.A.S., Wijayaratne L.K.W., Senanayake, D.P. and Palipane K.B., "Design, Construction and Operational Aspects of Paddy Husk Fired Furnaces for Drying and Entomolo gical Activities", World Engineers Convention, Shanghai, Chaina, Proc.568-573, 2004

13. Wagner, M.K. and Moberg L.J. Present and future use of traditional antimicrobials. Food Technology. 143-147., 1989 